\title{
Editorial 64
}

\author{
Eric Scerri ${ }^{1}$
}

Published online: 3 March 2020

(c) Springer Nature B.V. 2020

A large part of the current edition consists of a special issue that arose from the 22nd conference of our International Society for the Philosophy of Chemistry held in Bristol in the UK. Very sadly the organizer Geoffrey Blumenthal (http://www.bristol.ac.uk/school-ofarts/people/geoffrey-j-blumenthal/index.html) passed away soon after the meeting and after starting to edit these articles. Geoffrey came to the philosophy of chemistry late in life, while obtaining a $\mathrm{PhD}$ on the chemical revolution with James Ladyman at the University of Bristol. His dedication to the field was quite extraordinary as was his kindness towards everybody he came into contact with. He will be sorely missed.

What adds to this already great sadness is that since the last issue of this journal appeared we have also lost Rom Harré, our honorary president, who passed away in October of 2019 at the age of 91 . Rom was one of the most cited authors in the philosophy of science (About 80,000 citations according to the Google Scholar website, at the time of writing. https://scholar.google.com/citations?hl=en\&user=stDFY-MAAAAJ) who published about 70 books and over 500 academic articles. His work was best summed up in an obituary that appeared in the Times of London (https://www.thetimes.co.uk/article/romharr-obituary-zktbz0t8c),

Rom Harré was one of those people who seemed to have more hours in his day than anyone else. A polymath, who having begun teaching mathematics and physics, became an expert in psychology, sociology and philosophy, he would often spend his mornings in one discipline and his afternoons in another, all in time to attend a concert in the evening.

Harré served as president of ISPC for a period of about 10 years during which time his international reputation greatly helped to promote the study of the philosophy of chemistry. There is simply nobody among us to replace him.

Returning to the special issue for the Bristol meeting, this includes six articles beginning with one by Philip Stewart from the UK who writes on the periodic table of the elements.

Vanessa Seifert, a recent $\mathrm{PhD}$ from Bristol, and a colleague of Geoffrey Blumenthal who helped to organize the Bristol meeting, writes about the role of idealization in the description of isolated molecules.

Eric Scerri

scerri@chem.ucla.edu

1 Department of Chemistry and Biochemistry, UCLA, Los Angeles, CA, USA 
Michelle Friend who works mainly in the philosophy of mathematics and who is now based in Lille, France, discusses a formal language intended for the conceptual analysis of macroscopic chemical processes.

Justin Price from the University of South Carolina contributes an article on two cases of model transfer, namely the use of the ideal gas law in biology by R.A. Fisher and the use of the virial theorem in chemistry by Richard Bader.

Filip Buyse is a philosopher from Belgium whose area of expertise lies with Spinoza and early modern history and philosophy of science. His article in the current issue explores the views of Boyle, Spinoza and Glauber and how each of them wrote about the chemical saltpeter.

The special issue closes with an article that would have been of great interest to Rom Harré because it examines the role of affordance in overcoming skepticism about molecular structure. The author is Hirofumi Ochiai from Nagoya Bunri University in Japan.

The remainder of this issue consists of a variety of other articles starting with one from perhaps the world's leading expert on electron spin resonance, Gareth Eaton from Denver University where I have had the pleasure of speaking on two occasions. Eaton's article asks the question of who should be credited with various aspects of the discovery of isotopes, such as the first suggestion of the idea, the first experimental confirmation or the development of experimental methods concerned with isotopes. Eaton's contention is that Theodore Richards' experimental confirmation of isotopy deserves a great deal more credit than it has generally been given.

Jerry Diaz is a mathematical chemist based at the University of Missouri in Kansas City. His article surveys how the publication of Mendeleev's periodic table and the discovery of the electron has changed the teaching of chemistry.

Olimpia Lombardi is the most prominent philosopher of physics in Argentina as well as being its most prominent philosopher of chemistry. On this occasion she has teamed up with Cherif Matta from Halifax, Nova Scotia to re-examine the increasingly important issue of emergence in chemistry. I should also add that Olimpia and her colleagues are the organizers of the forthcoming 24th annual international conference that will be held in Buenos Aires from July 21st to 23rd (http://www.filoexactas.exactas.uba.ar/ispc2020/).

Finally, the issue closes with a book review by the distinguished historian of chemistry, Trevor Levere, of the Catalan author, Pere Grapís, history of air related science.

Publisher's Note Springer Nature remains neutral with regard to jurisdictional claims in published maps and institutional affiliations. 